園学雑. (J. Japan. Soc. Hort. Sci.) 56(1)：39-44. 1987.

\title{
トマト果実の成熟に伴らカルシウムの存在形態の変化 ${ }^{1}$
}

\author{
南出隆久 ${ }^{2}$ ・上田悦範・岩田 隆 \\ 大阪府立大学農学部 591 堺市百鳥梅町
}

\author{
Changes in Forms of Calcium in Tomato Fruit during Ripening \\ Takahisa Minamide, Yoshinori Ueda and Takashi Iwata \\ College of Agriculture, University of Osaka Prefecture \\ Mozu-umemachi, Sakai, Osaka 591
}

\begin{abstract}
Summary
Changes in pectic substances and calcium during ripening of tomato fruits on vine and after harvest were followed.

(1) Firmness and viscosity of the ripening fruits decreased. Protopectine also decreased, while soluble pectine increased.

(2) The total $\mathrm{Ca}$ content in tomato fruits was almost the same at all stages of maturity. There was a marked increase in the water soluble fraction and decrease in the $1 \mathrm{~N}-\mathrm{NaCl}$ soluble and $2 \%$-acetic acid soluble fraction between breaker and light pink stages. The increase of the water soluble form of $\mathrm{Ca}$ was attributable to an increase of $\mathrm{Ca}^{2+}$.

(3) ${ }^{45} \mathrm{CaCl}_{2}$ solution was administered to tomato fruits through the peduncle at each ripening stage. In immature fruits, high specific activity was observed mostly in $2 \%$-acetic acid soluble and $5 \%-\mathrm{HCl}$ soluble fractions. The percentage distribution of incorporated ${ }^{45} \mathrm{Ca}$ in the water soluble fraction increased during ripening.

(4) After applying ${ }^{45} \mathrm{Ca}$ at the mature green stage, the tomato fruits were ripened off the tree. The specific activity of ${ }^{45} \mathrm{Ca}$ increased in the water soluble fraction and decreased in the $2 \%$ - acetic acid soluble fraction between mature green and breaker stages.
\end{abstract}

\section{緒言}

カルシウム (Ca) は, 無機質中空素, リン, カリウム についで多く植物体に存在しており, その生理作用とし ては細胞壁, 細胞膜, 酵素蛋白質の構造の保持や機能の 調節を行っている $(4,5,21,26)$. また，細胞質や液胞の 反応調節，有機酸の中和，さらに細胞分裂や伸長などに も関与していることが知られている $(3,20,30)$.これら Ca が植物体中でどのような化学形態で存在しているか については，多くの研究者によって調べられている(10, 19,25). 筆者らも前報 (24)で青果物における Ca の存在 形態について調べたところ, 青果物の種類により存在形 態に相違があり，また収穫後においても植物体中で変化 することを認めた．とくに，パセリの苯の黄化過程でシ

\footnotetext{
1 1985年11月 4 日 受理

2 現在 京都府立大学生活科学部 606 京都市左京区下鴨
}

ュウ酸 $\mathrm{Ca}$ 画分の增加がアスコルビン酸の減少に伴い生 じることを明らかにした. 一方, 果実の成熟・追熟琴象 と Ca の生理作用については, リンゴ $(2,13,29)$ やト マ

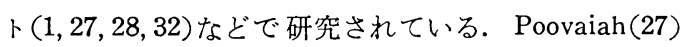
は，正常に成熟するトマト 'Rutgars' と成熟しない果実 'rin’を用いて Ca の存在形態を調べ, 'Rutgars' では結 合型 $\mathrm{Ca}$ が成熟に伴い1/3に減少するのに対し, 'rin'で はむしろ增加することを示した，また，Rigney とWills （28）はトマト果実の生育・成熟に伴う細胞壁中の $\mathrm{Ca}$ を調べ, 果実の生育初期には細胞壁中の $\mathrm{Ca}$ 含量は増加 し, その多くは結合型 $\mathrm{Ca}$ であるが, 内生ェチレンが生 成されるころになると結合型 $\mathrm{Ca}$ は一時減少し, 可溶性 Ca が増加することを認め, 果実の成熟開始に Ca が関 与していることを示唆した. しかし，これまでの研究 は，Ca を果実に処理することでその作用を調べている ものが多く, 果実組織内での Ca の存在形態や果実の成 
熟生理と $\mathrm{Ca}$ の代謝の関連性については上記両者の研究 がみられる程度でほとんど調べられていない。

本研究では, トマト果実の成熟と関連してペクチン物 質, $\mathrm{Ca}$ の存在形態, 並びに $\mathrm{Ca}$ の中でも生体膜の透過機 能の調節や酵素活性に重要な役割をもつ $\mathrm{Ca}^{2+}$ イオンな どの変化について調べた。 また, ${ }^{45} \mathrm{Ca}$ を果実の果梗より 吸収させトマト果実の成熟・追熟に伴う $\mathrm{Ca}$ 代謝の変化 についても検討した.

\section{材料及び方法}

\section{1. 材 料}

実験材料として，本学農場で栽培したトマト “鳳寿”を 用い，開花時にラベルを付け成熟を追って採取し分析に 供した。 また，熟度が mature green に相当するものを 採取し, $20^{\circ} \mathrm{C}$ の恒温室で追熟させた.

\section{2. ペクチン物質の抽出並びに定量}

トマト果実からのペクチン物質の抽出は, 果肉各 $50 \mathrm{~g}$ を用い $80 \%$ ェタノール不溶性物質を得て, Dolendo ら (9)の方法に従い, 水を加え $0^{\circ} \mathrm{C}$ で 1 昼夜静置後, 水溶 性ペクチンとプロトペクチンに分画した．各ペクチンは カルバゾール試薬により比色定量を行い, $500 \mathrm{~nm}$ にお ける吸光值を測定し，ガラクチュロン酸量として示し た(23).

\section{3. 果肉硬度並びに粘度の測定}

果実の成熟に伴ら果肉硬度の変化を調べるため，果実 の果頂部 (花落ち側) 周辺をカードメーター（飯尾電機 製）を用い，直径 $1 \mathrm{~mm}$ の円筒形プランジャーに荷重 $50 \mathrm{~g}$ の条件で果皮上より貫入し測定した．硬度はその時 の計数值で示した. 一方, 粘度は果肉 $20 \mathrm{~g}$ に等量の水 を加えホモジナイズした後，オストワルド粘度計を用い $20^{\circ} \mathrm{C}$ で測定した. 同時に水の粘度を計り，比粘度として 表した。

\section{4. 果実中における $\mathrm{Ca} の$ 存在形態と $\mathrm{Ca}^{2+}$ イ オンの測定}

トマト果実に含まれる $\mathrm{Ca}$ の存在形態を調べるため, 前報 (24) と同様小西・葛西の方法(19)に準じ，水溶性画 分 (F-I), 塩可溶性画分 (F-II), 酢酸可溶性画分 (FIII) 及び塩酸可溶性画分 (F-IV) に分別した. 各画分の $\mathrm{Ca}$ の測定は，原子吸光光度計（日立208型）を用い波長 $421.7 \mathrm{~nm}$ で行った. なお，共存元素の干涉を抑制する ために試料溶液に $1,000 \mathrm{ppm}$ の濃度になるようにラン タン（La）を添加した，F-I に存在する Ca イオンは, 柳沢・藤井(34)の方法により測定した。

\section{5. 果実の成熟に伴う Ca の代謝}

果実が成熟するに伴い， $\mathrm{Ca}$ の存在形態がどのように 変化するかを ${ }^{45} \mathrm{Ca}$ を用いて調べた. ${ }^{45} \mathrm{Ca}$ は ${ }^{45} \mathrm{CaCl}_{2}$
( $1 \mathrm{mCi}$ ，日本アイソトープ協会）を $1 \mu \mathrm{Ci} / \mathrm{ml}$ になるよ らに $1 \mathrm{mM} \mathrm{CaCl}_{2}$ を含む Tris- $\mathrm{HCl}$ 緩衝液 $(0.1 \mathrm{M}$, $\mathrm{pH}$ 7.4）に溶解した，果実に与えるストレスをなるべく 少なくするため，果実の果梗から自然に吸収させた。 こ の際, breaker 期までは果帯の有無にかかわらず果実へ の $\mathrm{Ca}$ 吸収には差異はみられなかったが，より熟期の進 んだものでは，果帯で吸収が止まり，果実へははとんど 取り込まれないことがわかった，そのため，本実験では 果帯を切除した果梗を ${ }^{45} \mathrm{Ca}$ を含む水溶液に浸漬し， 20 ${ }^{\circ} \mathrm{C}$ で24時間 $\mathrm{Ca}$ を吸収させた. 吸収後, 前述の方法によ り $\mathrm{Ca}$ を存在形態別に分け, 各画分への ${ }^{45} \mathrm{Ca}$ の取り込 みを $\mathrm{GM}$ カウンターで測定した. トマト果実は各熟度 で採取して調べるとともに, mature green の熟度のト マト果実に 24 時間 ${ }^{45} \mathrm{Ca}$ を吸収させた後, $20^{\circ} \mathrm{C} て ゙$ 追熟さ せ，追熟に伴う Ca 代謝の変化を調べた。

\section{結果}

\section{1.トマト果実の成熟に伴うぺクチン物翼,} 果肉硬度並びに粘度の変化

Small green の未熟果ではプロトペクチンがペクチン 物質の大部分を占め, mature green で若干低下し，そ の後果実が成熟するにつれて急減した. 水可溶性ぺクチ ンは，これと逆に成熟時に著しく増加した。この間の果 実の硬度は, プロトペクチンの変化とほぼ平行して成熟 とともに低下した，果肉の粘度は mature green 果まで は低かったが, breakerから dark pink 果にかけて明ら かに増加し，以後さらに急増することがわかった（第 1 図).このように，果実の成熟過程に打ける硬度や粘度 などの物理的変化は，プロトペクチンや可溶性ペクチン などのペクチン物質の変動とよく一致した。

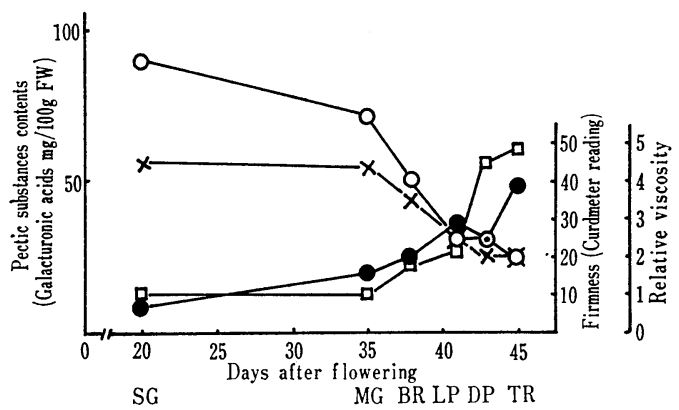

Fig. 1. Changes in pectic substance contents, firmness, and viscosity of tomato fruits during maturation.

$\bigcirc-\bigcirc:$ protopectin $\bullet \longrightarrow$ : soluble pectin $\times \longrightarrow \times$ : firmness $\quad \square-\square$ : relative viscosity Ripening stage $: \mathrm{SG}=$ small green, $\mathrm{MG}=$ mature green, $\mathrm{BR}=$ breaker, $\mathrm{LP}=$ light pink, $\mathrm{DP}=$ dark pink, $\mathrm{TR}=$ table ripe. 
Table 1. Changes of $\mathrm{Ca}$ form during maturation of tomato fruits.

\begin{tabular}{cccccccc}
\hline \hline & \multicolumn{7}{c}{ Days after flowering and ripening stage } \\
\cline { 2 - 7 } & 20 & 35 & 38 & 41 & 43 & 45 \\
\cline { 2 - 8 } & $\begin{array}{c}\text { Small } \\
\text { green }\end{array}$ & $\begin{array}{c}\text { Matur } \\
\text { green }\end{array}$ & Breaker & $\begin{array}{c}\text { Light } \\
\text { pink }\end{array}$ & $\begin{array}{c}\text { Dark } \\
\text { pink }\end{array}$ & $\begin{array}{c}\text { Table } \\
\text { ripe }\end{array}$ \\
\hline Total Ca & $10.17^{\mathbf{z}}$ & 10.21 & 10.41 & 10.38 & 9.62 & 9.85 \\
\hline F-I & $2.67^{\mathbf{z}}$ & 2.50 & 2.46 & 3.16 & 3.23 & 3.57 \\
F-II & 5.70 & 5.70 & 6.18 & 5.49 & 4.70 & 4.56 \\
F-III & 1.19 & 1.43 & 1.24 & 1.27 & 1.24 & 1.26 \\
F-IV & 0.61 & 0.58 & 0.53 & 0.46 & 0.45 & 0.46 \\
\hline Calcium ion/F-I (\%) & 9.5 & 15.6 & 14.2 & 27.7 & 30.0 & 33.6 \\
\hline
\end{tabular}

${ }^{z} \mathrm{mg} / 100 \mathrm{~g} \mathrm{Fw}$.

y $\mathrm{F}-\mathrm{I}$ : water soluble $\mathrm{Ca}, \mathrm{F}-\mathrm{II}: \mathrm{NaCl}$ soluble $\mathrm{Ca}, \mathrm{F}-\mathrm{III}:$ Acetic acid soluble $\mathrm{Ca}, \mathrm{F}-\mathrm{IV}: \mathrm{HCl}$ soluble $\mathrm{Ca}$.

Table 2. Incorporation of ${ }^{45} \mathrm{Ca}$ in different maturity of tomato fruits ${ }^{2}$.

\begin{tabular}{ccccccc}
\hline Ripening stage & $\begin{array}{c}\text { Small } \\
\text { green }\end{array}$ & $\begin{array}{c}\text { Mature } \\
\text { green }\end{array}$ & Breaker & $\begin{array}{c}\text { Light } \\
\text { pink }\end{array}$ & $\begin{array}{c}\text { Dark } \\
\text { pink }\end{array}$ & $\begin{array}{c}\text { Table } \\
\text { ripe }\end{array}$ \\
\hline F-I & $98.8^{\mathbf{x}}$ & 231.2 & 273.9 & 133.2 & 134.9 & 120.7 \\
F-II & $(15.0)$ & $(26.4)$ & $(35.6)$ & $(41.1)$ & $(42.1)$ & $(40.2)$ \\
F-III & 94.9 & 116.3 & 91.4 & 48.8 & 67.6 & 57.4 \\
& $(14.4)$ & $(13.3)$ & $(11.9)$ & $(15.0)$ & $(21.1)$ & $(19.1)$ \\
F-IV & 294.1 & 339.1 & 291.9 & 114.2 & 100.0 & 109.5 \\
& $(44.7)$ & $(38.7)$ & $(38.0)$ & $(35.2)$ & $(31.2)$ & $(36.4)$ \\
& 170.4 & 189.6 & 111.3 & 28.2 & 17.7 & 13.0 \\
\hline
\end{tabular}

$z$ Peduncle attached to tomato fruit without disk was immersed in $0.1 \mathrm{M}$ Tris/HCl buffer (pH 7.4) containing $1 \mathrm{mM} \mathrm{CaCl}_{2}$ and ${ }^{45} \mathrm{CaCl}_{2}(1 \mu \mathrm{ci} / \mathrm{ml})$ at $20^{\circ} \mathrm{C}$ for $24 \mathrm{hr}$, and distribution of specific radioactivity in each fraction was determined.

y Fraction mentioned as in Table 1.

$\times \times 10^{3} \mathrm{cpm} / \mathrm{mg} \mathrm{Ca}$. Percentage distribution of each fraction is in parentheses.

\section{2. 果実の成熟に伴う $\mathrm{Ca}$ の存在形態の変化} 結果は第 1 表のように, トマト果肉中の総 $\mathrm{Ca}$ 量は成 熟過程を通じて 9.62〜 $10.38 \mathrm{mg} / 100 \mathrm{~g}$ 新鮮重とほぼ一 定であった。 また，果実組織中に拈ける Ca は F-II に 最も多く, 次に F-I, F-III, F-IV の順で果実の成熟過 程を通じ順位は変わらなかった，F-I は breaker 果まで は成熟に伴いやや減少したが，果実の着色・軟化ととも に急増し, table ripe 果では総 $\mathrm{Ca}$ の約36\%を占めるに 至った. 一方, F-II と IV は果実の成熟の進行に伴い減 少したが，F-III は成熟過程を通じてあまり変化しなか った.

次に, 植物の生理作用に重要な役割を果している $\mathrm{Ca}^{2+}$ イオン含量を測定した. F-Iに含まれる $\mathrm{Ca}^{2+} の$ 割合は果実の成熟に伴い顕著な増加を示し，ことに breaker から light pink の段階にかけて急増した.この 割合は table ripe 果では small green 果に比べ約3.5倍 にも増加し， F-I の $\mathrm{Ca}$ 量の $33.6 \%$ になで達した. つま り, F-I の $\mathrm{Ca}$ 量の急増は $\mathrm{Ca}^{2+}$ の増加によるものであ
ることがわかった. なお, mature green 果を $20^{\circ} \mathrm{C} て ゙$ 追 熟させ, 追熟に伴う $\mathrm{Ca}$ の存在形態の変化を調べたが, 結果は第 1 表の樹上成熟果のものと同じ傾向であった.

\section{3. 果実の成熟・追熟に伴う $\mathbf{C a} の$ 代謝}

$\mathrm{Ca}$ の代謝を調べるため， ${ }^{45} \mathrm{Ca}$ をトマト果実の果梗よ り吸収させ, 各画分の分布状態を測定した.

まず，各熟度の果実に ${ }^{45} \mathrm{Ca}$ を24時間吸収させ，存在 形態別分布を調べ， ${ }^{45} \mathrm{Ca}$ の比放射活性で示した（第 2 表). Small green 果では, 取り込まれた ${ }^{45} \mathrm{Ca} の$ 多くは F-III と F-IV に高い比放射活性で存在しており，F-I と F-II はほぼ同程度の活性であった。より熟度が進ん だ mature green や breaker 果では, F-III に高い比放 射活性を示しているが，F-I にも多くなることがわかっ た. Light pink 期以降の熟度の果実では，果带を除いた にもかかわらず ${ }^{45} \mathrm{Ca}$ の吸収の絶対量は，それ以前の熟 度のものに比べ半分程度になった. Light pink 以後の 存在形態分布には著しい変化はみられず, F-I と F-III にその比活性が高く取り込まれた。 


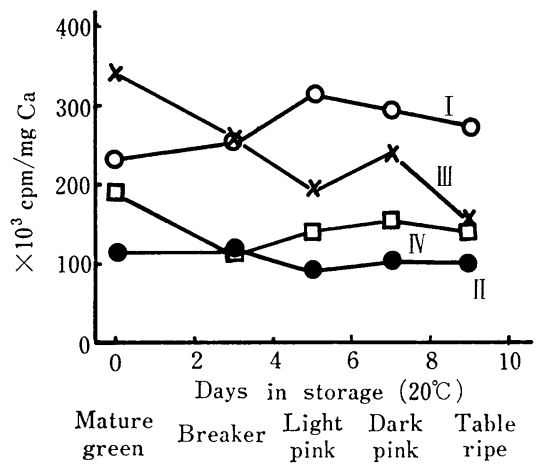

Fig. 2. Metabolism of ${ }^{45} \mathrm{Ca}$ incorporated in mature green tomato during ripening.

Tomato fruits at mature green were treated with ${ }^{45} \mathrm{CaCl}_{2}$ solution as described in Table 2 and ripened at $20^{\circ} \mathrm{C}$.

次いで mature green 果に ${ }^{45} \mathrm{Ca}$ を吸収させ,トマト を $20^{\circ} \mathrm{C}$ に眝蔵し, 果実の追熟に伴う ${ }^{45} \mathrm{Ca}$ の比放射活性 の変化を調べた、第 2 図からも明らかなように mature green 果で多く吸収された F-III の ${ }^{45} \mathrm{Ca}$ は, breaker から light pink 期に減少し, F-I はその比活性が增加し た，F-II，F-IV の比活性は追熟に伴い汪とんど変化が なかった。

\section{考察}

果実は成熟するにしたがい，果皮や果肉の着色，果肉 の軟化, 香りの生成・発散, 酸・甘味の变化などが生じ 食味が良くなる。これらの現象のらち，果肉の軟化は細 胞壁の構造変化と密接汇関係している，細胞中葉にはぺ クチン質が多く含まれ，細胞間を結び付けているが，Ca はペクチン物質と複合体を作り細胞中葉を固め，その構 造を保持している(11)，果実が軟らかくなるのは，この 中葉を構成するペクチン物質が分解し可溶化されること と関係が深い(15)，トマト果実においても，組織の硬さ や粘性にペクチン質が関与していることが多くの研究者 によって報告されている $(1,7,14,16)$. 今回の実験にお いても同じような結果が得られ（第 1 図），トマト果実 の硬度の低下は，プロトペクチンの減少と水溶性ペクチ ンの增加を伴っており，これらの変化は mature green から light pink 期に顕著であった. 果肉の粘性は light pink 期を過ぎたころから著しい増加を示したことから， リンゴ(17) と同様，可溶性ペクチンが粘性の增加をもた らしたものと思われる。 ペクチンの分解には, poly-galacturonase $(\mathrm{PG})$ と pectine esterase (PE) が関与して おり, Rigney と Wills(28) はペクチン物質を脱ポリマ 一化する PG は $10^{-7} \mathrm{M}$ 程度の $\mathrm{Ca}$ で活性が阻害される のに対し，PE の活性には $\mathrm{Ca}$ が必要であることを指摘
した．本実験ではこれら酵素の活性変化を調べていない が, $\mathrm{Ca}$ の可溶化が生じるとともに $\mathrm{Ca}^{2+}$ イオンが急增す る breaker から light pink 期（第1表）までに PGに よりプロトペクチンの分解が始まっており，その後, 組 織中に增加した $\mathrm{Ca}^{2+}$ イオンが $\mathrm{PE}$ を活性化させ果肉の 軟化をもたらすものと思われる.

果実中の F-I の $\mathrm{Ca}$ の大部分は, 有機酸塩として液胞 や細胞質に存在しているものと思われるが，その中には 植物の生理作用に重要な役割を果している $\mathrm{Ca}^{2+}$ イオン も含まれている。細胞中の $\mathrm{Ca}^{2+}$ 濃度は10-6から $10^{-8} \mathrm{M}$ 程度 $(21)$ といわれている。本実験では F-I に占める $\mathrm{Ca}^{2+}$ は small green 果では約10\%, table ripe 果では $33.6 \%$ であり，これは全 $\mathrm{Ca}$ のそれぞれ $2.5 \%$ 及び 12.2 \%に相当し，成熟に伴い多くなることがわかった．しか も， $\mathrm{Ca}^{2+}$ は breaker から light pink 期に急增した. 果 実の成熟過程のなかでも，この時期が呼吸の急増期ない し，クライマクテリックピーク期に当たり，各種生理作 用が活発に行われているところから，組織中に増加した $\mathrm{Ca}^{2+}$ は細胞膜や ミトコンドリア膜などのリン脂質と結 合し(33), その透過機能を調節したり $(8,31)$, lipoxygenase(18), phospholipase(22), pectin esterase(12)など 果実成熟時の酵素活性の增大に寄与するものと推察され る.

mature green から light pink 期に生じる $\mathrm{Ca}$ の可溶 化現象を $\mathrm{Ca}$ 代謝の面から明らかにするため, ${ }^{45} \mathrm{Ca}$ を果 梗より吸収させる方法で調べた。トマト果実の生育は開 花後 $1 \sim 2$ 週間で細胞分裂が終了し, 細胞の増殖はこの ころまでに完了する(15). 本実験で用いた small green 果は, 開花後 20 日のものであり, 細胞は肥大生育期に入 っている。この時期に吸収された ${ }^{45} \mathrm{Ca}$ は，主にリン酸 塩 (F-III) やシュウ酸塩 (F-IV) として高い比放射活 性で存在し，果実細胞が肥大生育期に入っているにもか かわらずペクチン物質や蛋白質画分（F-II）にわずかの 比放射活性でしか取り込まれなかった（第 2 表）。この ことは, F-II 画分の Ca の多くは開花後20日までに既に 細胞壁構造に組み込まれることを示しており，果実の成 熟現象における Ca の生理作用を調べる上で興味ある結 果である.ささらに成熟が進み，Ca の可溶化現象の起こ る mature green から breaker にかけて F-I に取り込 まれる ${ }^{45} \mathrm{Ca}$ の比放射活性が増加し，他の画分からの Ca の移行が示唆された.

さらに, ${ }^{45} \mathrm{Ca} を$ mature green の果実に取り込ませ, 追熟させて，追熟過程における $\mathrm{Ca}$ の代謝を調べたとこ ろ, mature green から light pink 期にかけ, F-III の 比放射活性の減少，F-I の増加がみられた（第 2 困). 
これらの結果から，トマト果実のクライマクテリック 時にみられる $\mathrm{Ca}$ の可溶化現象は, $\mathrm{Ca}$ 含量の変化（第 1 表）からみて F-II 画分からもたらされるものと思われ るが，F-III 画分の Ca も F-II から F-I の代謝途中か あるいはそれと無関係に $\mathrm{Ca}$ 代謝に関与しているものと 思われる．すなわち，F-III は熟度が進んでも Ca 含 量変化は示さないが， $\mathrm{Ca}$ 交換を活発に行い, mature green の時期に高い比放射活性で取り込んだ ${ }^{45} \mathrm{Ca}$ を F-I に移行しているものと思われるが，さらに詳しい研 究を要すると考えられる.

\section{摘 要}

トマト果実の成熟・追熟過程について，軟化と関係の 深いペクチン物質, 並びに細胞壁・生体膜の構造保持や 機能に作用するカルシウム（Ca）の動向を調べた.

1.トマト果実は成熟するにしたがい軟化し，果肉の 粘度は増大した。 その間に, プロトペクチン含量が減少 し可溶性ペクチン含量が増加した. とくに, breaker か ら dark pink 期にかけて顕著であった。

2.トマト果実の $\mathrm{Ca}$ を存在形態別に分画, 測定した ところ, 各熟度の果実とも塩可溶画分 (F-II) に最も多 く含まれ, 次に水可溶性画分 $(\mathrm{F}-\mathrm{I})$, 酢酸可溶性画分 (F-III), 塩酸可溶性画分 (F-IV) の順であった。果実 の成熟に伴う変動は break 期まではあまりみられず, breaker 期以後熟度が進むにつれ F-I の増加, F-II 及 び F-IV の減少がみられた。 また，F-I 中の $\mathrm{Ca}^{2+}$ イオ ン量は breaker 期を過ぎると急激に増加することがわ かった。

3. 各熟度の果実に ${ }^{45} \mathrm{Ca}$ を果梗より吸収させ，果実 の成熟に伴って，吸収された ${ }^{45} \mathrm{Ca}$ の分布を比放射活性 $\left({ }^{45} \mathrm{Ca}\right.$ カウント/Ca 含量) で調べた. small green や mature green 果実では, ${ }^{45} \mathrm{Ca}$ は F-III やF-IVで高い 活性を示した. breaker から light pink 期にかけて果実 への ${ }^{45} \mathrm{Ca}$ の吸収の総量は低下したが，F-I 画分への取 り込みの割合は多くなった。

4. mature green 果実に ${ }^{45} \mathrm{Ca}$ を吸収させ，トマトを 追熟させて $\mathrm{Ca}$ 代謝を調べたところ, mature green か ら light pink 期にかけて Ca 代謝に変化がみられ, ${ }^{45} \mathrm{Ca}$ の比放射活性の F-III での低下と F-I での増加がみら れた。

\section{引用文献}

1. Brady, C. J., W. B. Mcglasson, J. A. Pearson, S. K. MELDRUM and E. KOPELIOVITCH. 1985. Interactions between the amount and molecular forms of polygalacturonase, calcium, and firmness in tomato fruit. J. Amer. Soc. Hort. Sci. $110: 254-258$.
2. Bramlage, W. J., M. Drake and J. H. BAKER. 1974. Relationships of calcium content to respiration and postharvest condition of apples. J. Amer. Soc. Hort. Sci. 99 : 376-378.

3. 陳 文孝.上本俊平. 1976. そ菜のカルシウム吸 収に関する研究. 第 1 報. そ菜の異なった生長相 におけるカルシウム吸収とその生理的意義. 園学 雑. $45: 33-42$.

4. Christiansen, M. N. and C. D. Foy. 1979. Fate and function of calcium in tissue. Commun. Soil Sci. and Plant Anal. $10: 427-$ 442.

5. ClaRkSON, D. T. and J. B. HANSON. 1980. The mineral nutrition of higher plants. Annu. Rev. Plant Physiol. $31: 239-298$.

6. Collier, G. F. and V. C. Huntington. 1983. The relationship between leaf growth, calcium accumulation and distribution, and tipburn development in fleld grown butterhead lettuce. Scientia Hort. 21 : 123-128.

7. Deshrande, S. N., W. J. Klinker, H. N. DraudT and N.W. DESROSIER. 1965. Role of pectic constituents and polyvalent ions in firmness of canned tomatoes. J. Food Sci. 30 : 594600.

8. Dieter, P. and D. MARMÉ. 1980. $\mathrm{Ca}^{2+}$ transport in mitochondrial and microsomal fractions from higher plants. Planta $150: 1-8$.

9. Dolendo, A. L., B. S. LUH and H. K. PRATT. 1966. Relation of pectic and fatty acid changes to respiration rate during ripening of avocado fruits. J. Food Sci. $31: 332-336$.

10. FERGUSON, I. B., N. A. TURNER and E. G. BOLLARD. 1980. Problems in fractionating calcium in plant tissue. J. Sci. Food Agric. $31: 7-14$.

11. Grant, G. T., E. R. Morris, D. P. REES, P. J. C. SMITH and D. THOM. 1973. Biological interactions between polysaccharides and divalent cations: The egg-box model. FEBS Let. $32:$ 195-198.

12. HANCOCK, J. G. and M. E. STANGHELlini. 1968. Calcium localization in Hypomycesinfected squash hypocotyls and effect of calcium on pectate lyase activity and tissue maceration. Can. J. Bot. $46:$ 405-409.

13. Himelrick, D. G. 1981. Determination of total and ionic calcium in apple leaf and fruit tissues. J. Amer. Soc. Hort. Sci. 106 : $619-621$.

14. HoBSON, G. E. 1965. The firmness of tomato fruit in relation to polygalacturonase activity. J. Hort. Sci. $40: 66-72$.

15. HoBSON, G. E. 1981. Enzymes and texture changes during ripening. p. 123-132. In : J. 
FRIEND and M. J. C. RHODES (eds.) Recent Advances in the Biochemistry of Fruit and Vegetables. Academic Press. London and New York.

16. 飯野久栄・小筸戸和夫. 1977.トマトの成熟なら びに搾汁におけるペクチンの変化. 食品工誌. $24: 350-356$.

17. KNEE, M. 1978. Properties of polygalacturonate and cell cohesion in apple fruit cortical tissue. Phytochemistry $17: 1257-1260$.

18. КоCH, R. B. 1968. Calcium ion activation of lipoxidase. Arch. Biochem. Biophys. 125 : 303-307.

19. 小西茂毅・葛西善三郎. 1963. タバコ葉の Ageing にともなうカルシウムの代謝（その 1)一生 育各期に吸収された ${ }^{45} \mathrm{Ca}$ の形態変化. 土肥誌. $34: 67-70$.

20. KONNO, H., T. YamaYA, Y. YamaSAKI and $H$. MATSUMOTO. 1984. Pectic polysaccharide breakdown of cell wall in cucumber roots grown with calcium starvation. Plant Physiol. $76: 633-637$.

21. MARMÉ, D. 1983. Calcium transport and function. p. 599-625. In : LÄUCHLI, A. and R. L. BIELESKI (eds.) Inorganic plant nutrition. vol. 15 B. Springer-Verlag. Berlin.

22. MASORO,E. J. and B.P. YU. 1971. The functioning of the lipids and lipoproteins of sarcotubular membranes in calcium transport. Lipid. $6: 357-368$.

23. McCOMB, E. A. and R. M. McCREADY. 1952. Colorimetric determination of pectic substances. Anal. Chem. 24 : 1630-1632.

24. 南出隆久. 後藤昌弘・岩田 隆. 1986. 青果物に おけるカルシウム (Ca) の存在形態の相違と収穫 後変の化. 園学雑. $54: 507-513$.

25. 太田安定・山本和子・出口正夫. 1970. カルシウ
么供給量，葉位，個体の生育段階の違いが水稲生 葉内カルシウムの化学形態分布におよぼす影響. 第 1 報. 各種植物体内カルシウムの化学形態別分 布. 土肥誌. $41: 19-25$.

26. 太田安定. 1975. カルシウムの生理作用. p. 92102. 植物栄養土壌肥料大事典. 養賢堂. 東京.

27. POOVAIAH, B. W. 1979. Role of calcium in ripening and senescence. Commun. Soil Sci. and Plant Anal. $10: 83-88$.

28. RigNEY, C. J. and R. B. H. Wills. 1981. Calcium movement, a regulating factor in the initiation of tomato fruit ripening. HortScience $16: 550-551$.

29. SAMS, C. E. and W. S. CONWAY. 1984. Effect of calcium infiltration on ethylene production, respiration rate, soluble polyuronide content, and quality of 'Golden Delicious' apple fruit. J. Amer. Soc. Hort. Sci. 109 : $53-57$.

30. 鈴木鉄男 - 金原敏治 - 榊原正義 - 深井尚也. 1972. リン酸および石灰の施用が温州ミカンの生 育と結実に及ぼす影響. 園学雑. 41 : 157-164.

31. VANSTEVENINCK, R.F.M. 1965. The significance of calcium on the apparent permeability of cell membranes and the effects of substitution with other divalent ions. Physicl. Plant. $18: 54-69$.

32. Wills, R. B. H. and S. I. H. TIRMAZI. 1979. Effect of calcium and other minerals on ripening of tomatoes. Aust. J. Plant Physiol. $6: 221-227$.

33. Wolman, M. and H. Wiener. 1963. Changes in the constitution of myelin caused by ions. Nature $200: 886-887$.

34. 柳沢文正・藤井嘉寿. 1955. 食品のカルシウムイ オン測定法と測定值について. 栄養と食糧. 7 : 220 . 